\title{
INFLUENCE OF ECONOMIC SPACE IMBALANCES ON THE FUNCTIONING OF THE ENTERPRISE FINANCIAL MECHANISM
}

\author{
Lidiia Fedoryshyna ${ }^{1}$, Nataliia Vilchynska ${ }^{2}$
}

\begin{abstract}
The purpose of this article is to analyse the nature of imbalances in the economic space, as the problem of impact on the functioning of the financial mechanism of the enterprise is especially relevant for Ukraine, because the results of the domestic financial sector are unbalanced. At the same time, a significant impact is reflected in the functioning of the financial mechanism of the enterprise, expanding its functional load. The instability of economic conditions in Ukraine significantly affects the financial and economic activities of economic entities, which causes non-fulfilment of their planned tasks for the development of their own business. To ensure the successful operation, enterprises must assess the imbalances of the economic space, which are precursors to the development of crisis processes that can have a devastating effect. Methodology. In the course of the research it has been found that the financial mechanism of the enterprise is subject to influence both at the level of the enterprise itself and at the level of economic space. It is determined that the main source of information on the imbalance of the economic space is the balance of payments. Balance of payments is the ratio between the amount of cash received by the country from abroad and the amount of payments abroad during a certain period (year, quarter, month). The main component of the balance of payments is the current account, and the most important item is the balance of goods (trade balance). Its condition determines the state of the balance of payments as a whole, and its dynamics demonstrates the effectiveness of macroeconomic policy. The positive balance of trade indicates an increase in demand for goods and services of the country. The negative balance indicates the low competitiveness of the country's goods abroad. In the case when the value of exports exceeds the value of imports, a trade surplus is formed. If the value of imports exceeds the value of exports, then there is a trade deficit. The financial account of the balance of payments reflects the sale and repayment of financial claims of one country to another. All financial transactions are classified into three groups: direct investment, portfolio investment, and other investments. The dynamics of the financial account during the study period is negative. This indicator was affected by the crisis in the economy, as well as imperfect legislative support for foreign investors in Ukraine. Results. Theoretical information and structure of the balance of payments are presented, balance of payments articles are analysed, the dynamics of the balance of payments of Ukraine is outlined. The main feature of 2015-2019 is the strengthening of globalization. The intensification of relations between the countries leads to a stronger integration of the whole economy, which in turn creates additional risks associated with the transmission of possible crises in the chain. Value/originality. It is established that the functioning of the financial mechanism of the enterprise is considered under the influence of many factors of the system, in particular economic space. The generation of these imbalances leads to an increase in the vulnerability of the financial mechanism, violating the stability, which is manifested in the inability to resist changes in the situation. By assessing the imbalances of the economic space on the basis of macroeconomic and monetary indicators obtained during the monitoring, economic entities will be able to counteract shocks in the event of a change in the situation.
\end{abstract}

Key words: imbalances, economic space, financial mechanism, balance of payments.

JEL Classification: E40, E43, E44, E50, E52, F30, F40

\footnotetext{
Corresponding author:

${ }^{1}$ Vinnytsia National Agrarian University, Ukraine.

E-mail: fedorishina@i.ua

ORCID: https://orcid.org/0000-0003-3072-4854

ResearcherID: L-5746-2018

${ }^{2}$ Vinnytsia National Agrarian University, Ukraine.

E-mail: natavilchin@gmail.com

ORCID: https://orcid.org/0000-0002-3246-2096
} 


\section{Introduction}

Unpredictable socio-economic changes caused by imbalances in recent years have been the main impediments to Ukraine's development. Based on the vision of imbalance as a source of crisis, scientists focus on the mechanism of flow of external imbalances into internal and vice versa. These processes have a significant impact on the financial performance of economic entities. At the same time, a significant impact is reflected in the functioning of the financial mechanism of the enterprise, expanding its functional load. Thus, understanding the essence of such processes is a prerequisite for their timely recognition and prevention.

The study of the impact of imbalances in the economic space on the functioning of the financial mechanism of the enterprise should begin with an analysis of general trends in the economy of Ukraine in recent years. This is important because on this basis it is possible to determine and understand the nature of the imbalances of the economic space in all their varieties. In addition it is necessary to outline the preconditions by which the deep unevenness of the economic space is realized in the manifestations and consequences of imbalances.

The aim of the article is to study the nature imbalances of the economic space, determine the features of their manifestation and assess their impact on the functioning of the financial mechanism of the enterprise.

The instability of economic conditions in Ukraine significantly affects the financial and economic activities of economic entities which causes non-fulfilment of their planned tasks for the development of their own business. To ensure the successful operation, enterprises must assess the imbalances of the economic space which are precursors to the development of crisis processes that can have a devastating effect.

Turning to the theoretical foundations it should be noted that the economic category of "imbalance" is quite new and has many semantic nuances and interpretations. In the modern scientific literature the concept of "imbalance" is defined as a violation of economic equilibrium, balance of processes, flows in the company, region, state or unbalanced condition of the object or violation of parameters that characterize the object as a whole and processes of change in functioning and development of the object.
Among domestic scientists, the study of the nature of imbalances can be found in the works by T. Savchenko, who treats imbalances or disequilibrium as an intrinsic property of a market economy, which "follows" from its nature, and equilibrium is only its temporary state.

In the EU Regulatory Act № 1176/2011 “On the prevention and correction of macroeconomic imbalances", the term "imbalance" is defined as any trend that gives rise to macroeconomic trends that adversely affect the normal functioning of the economy of a Member State of the economic and monetary Union or the EU as a whole.

A. Apokin defines the essence of the imbalance more narrowly and notes first of all the ongoing imbalance of debt and credit in the world economy. In our opinion, $\mathrm{K}$. Borio justifies the definition of imbalances more comprehensively. The author of the definitions identify imbalances as "overstrain" of the balance sheets of economic entities as a result of a sharp rise in asset prices and external financing which usually leads to a decrease in the stability of the economic system and a deepening subsequent recession.

\section{Economic crisis effects on consumer behaviour}

After analysing the scientific literature we can distinguish two approaches to determining the nature of imbalances. The first approach focuses on disturbing the dynamic balance between needs and the actual available amount of financial resources. The second approach is based on international asymmetries in supply and demand for assets.

Economic space is defined as a set of economic interests that ensure the effective functioning of the state at the global, national, regional and local levels [8]. Since economic interests are the benefits that are achieved in the process of economic relations, they allow economic agents to obtain a certain result to meet their needs.

Despite the widespread use of the concept of "space", there is no unambiguous interpretation of its content in the scientific literature today, because there are two groups of interpretation of the definition of space - socio-economic and philosophical. Each of them complements and expands the general idea of this phenomenon. Their difference is that the former have a direct connection between habitat and human activity but for the latter this connection is indirect. Economic space is defined as a set of economic interests that 
ensure the effective functioning of the state at the global, national, regional and local levels needs.

Thus, imbalances in the economic space are imbalances due to the influence of certain factors that lead to deviations from the equilibrium state and cause the failure to achieve economic interests.

The magnitude of imbalances in the economic space can be influenced through the financial mechanism which is a kind of "circulatory system" of the economy and in the case of proper regulation of financial flows within the enterprise will provide a stable rate of economic growth.

Financial mechanism is a set of forms and methods of external and internal influences on the formation, use and accumulation of financial resources in order to ensure their economic activity of the enterprise and increase the efficiency and profitability of production (Plakhtii, Fedoryshyna, Tomchuk, 2019). In this definition, the financial mechanism is characterized as a device that transmits the influence of the external environment to the enterprise and realizes the influence of the internal environment of the enterprise. Financial and economic factors are of particular influence on the enterprises' financial resources. They reflect the level of economic development, the financial market, the investment climate in the country and the stability of the domestic financial system.

According to scientists in the event of adverse developments, economic imbalances are likely to be the main catalyst for the financial crisis. P. Krugman emphasizes that the main cause of the financial crisis is the imbalance of the balance of payments (Plakhtii, Fedoryshyna, Tomchuk, 2019).

Balance of payments is a key concept in the tool of the international economy because it systematizes and allows you to analyse the country's relationship with the outside world. It is through the study and analysis of the balance of payments that the government can understand macroeconomic imbalances not only in terms of its national interests but also in terms of the country's multilateral ties with the world economic community (Donald B. Kraybill, 1989).

The study of the balance of payments gives grounds for understanding economic imbalances from the standpoint of the internal state of the country and the diversity of the country's relations with the international economy. The dynamics of change in the state of its individual articles reflects the main trends of economic development of the country and as a consequence can be the main source of information for decision-making in financial regulation. The formation of the balance of payments is carried out under the influence of factors of economic and non-economic origin.

\section{Differences in consumer spending behaviour among age groups}

In most countries, balances of payments are developed according to the scheme recommended by the International Monetary Fund (Kubicek, 2005). Structurally, the main components of the balance of payments are grouped into the following accounts: current account, capital account and financial account. Table 1 summarizes the balance of payments of Ukraine since 2015.

Ukraine's balance of payments has returned to surplus since 2015 (David Ransom). The positive balance is primarily due to a significant reduction in the current account deficit. Analysing the structure of balance of payments in Ukraine, it should be noted that the current account and financial account since 2016 have negative values. Thus, the current account deficit in 2019 is 1.062 billion USD and indicates deterioration in foreign trade in goods. Analysing the dynamics of balance of payments accounts, in particular current transactions it should be noted that the highest level of deficit was achieved in 2018.

The main component of the balance of payments is the current account and the most important item is the balance of goods (trade balance).

Its condition determines the state of the balance of payments as a whole and its dynamics demonstrates the effectiveness of macroeconomic policy. The positive balance of trade indicates an increase in demand for goods and services of the country. The negative balance indicates the low competitiveness of the country's goods abroad. In the case when the value of exports exceeds the value of imports, a trade

Table 1

Dynamics of balance of payments items of Ukraine, million USD

\begin{tabular}{|l|c|c|c|c|c|}
\hline & 2015 & 2016 & 2017 & 2018 & 2019 \\
\hline Current account & 1616 & -1340 & -2442 & -4367 & -1322 \\
\hline Capital account & 456 & 92 & -4 & 37 & 38 \\
\hline Financial account & 1223 & -2594 & -5012 & -7207 & -7264 \\
\hline Consolidated balance & 849 & 1346 & 2566 & 2877 & 5980 \\
\hline
\end{tabular}


Table 2

Dynamics of the trade balance of Ukraine, million USD

\begin{tabular}{|l|c|c|c|c|}
\hline \multicolumn{1}{|c|}{ Indexes } & 2015 & 2016 & 2017 & 2018 \\
\hline Export of goods & 35420 & 33560 & 39701 & 43341 \\
Import of goods & 38875 & 40502 & 49364 & 56055 \\
\hline Balance of goods & -3455 & -6942 & -9663 & -12714 \\
\hline Export of services & 12442 & 12448 & 14167 & 15794 \\
Import of services & 11349 & 11959 & 13148 & 14447 \\
\hline Balance of services & 1093 & 489 & 1019 & 1734 \\
\hline Balance & -2362 & -6453 & -8644 & -11367 \\
\hline
\end{tabular}

surplus is formed. If the value of imports exceeds the value of exports then there is a trade deficit.

Table 2 summarizes data on exports, imports, as well as the trade balance of Ukraine for 2015-2019. Analysis of the dynamics of changes in Ukraine's trade balance over the years is negative, which means that imports of goods exceed their exports. In recent years, the trade balance has deteriorated significantly, this figure in 2019 increased 5 times. This situation is explained by the fact that the commodity structure of exports and imports has remained unchanged over the last ten years. It should be noted that during this period, exports decreased by 10,695 million dollars USD and imports of goods and 21187 million USD.

The second most important item of the current account of the balance of payments is the item "Balance of services". It has a positive value and since 2016 has a steady upward trend. Thus, if in 2015 the export of services amounted to 12,442 million USD; in 2019 it increased by $38 \%$ and amounted to 17,265 million USD. This is due to the increase in the costs of Ukrainians traveling abroad, increasing revenues from information and computer services. Due to the stable positive balance under this article, the negative balance on the current account as a whole is partially compensated.

\section{Findings}

The capital account reflects net lending (borrowing). This account has no significant impact on the balance of payments.

The financial account of the balance of payments reflects the sale and repayment of financial claims of one country to another. All financial transactions are classified into three groups: direct investment, portfolio investment, other investment. The dynamics of financial accounting during the study period is negative. This indicator was affected by the crisis in the economy, as well as imperfect legislative support for foreign investors in Ukraine (Table 3).

The items "Direct investment" and "Other investment" of the financial account of the balance of payments provide the maximum amount of receipts of funds attracted to the account of foreign direct investment. During the period from 2015 to 2019 achieving direct investment will be slightly reduced. In 2019 the figure is 2422 million USD which is almost 1.3 times less than in 2016. This trend depends on a decrease in the transition from direct investment to equity instruments. The amount of portfolio investment decreased 14 times which indicates a negative mood among investors. The devaluation of the hryvnia causes an outflow of capital from countries which leads to an imbalance that affects the economic activity of economic entities.

\section{Conclusions}

Analysing the balance of payments of accounts allows to determine which of them have the greatest impact on the balance and imbalance. In particular the negative current account balance during 2016-2019 indicates the need for regulatory action. The state of Ukraine's balance of payments changed significantly during the period under review which was reflected in its balance and in the structure of individual accounts. But despite the fact that at present its condition has

Table 3

Dynamics of financial account items of Ukraine, million USD

\begin{tabular}{|l|c|c|c|c|c|}
\hline \multicolumn{1}{|c|}{ Indexes } & 2015 & 2016 & 2017 & 2018 & 2019 \\
\hline Direct investment & -3012 & -3268 & -2593 & -2360 & -2422 \\
\hline Portfolio investments & -367 & -293 & -1800 & -2080 & -5134 \\
\hline Other investments & 4263 & 392 & -137 & -1061 & 1538 \\
\hline
\end{tabular}


significantly improved compared to the beginning of the study period, the existing economic realities necessitate further search for sources of capital inflows into the country, as well as numerous transformations in the economy.

Ukraine's balance of payments is a rather complex system of influencing various aspects of economic activity of individual entities. The main vector of this influence is the relationship with the state which produces and implements financial policy with economic entities that ensure the production of GDP. The balance of payments deficit (surplus) spills over into the crisis of the national economy which further deepens the imbalances that significantly affect the financial condition of economic entities. Thus, imbalances in the country's economy cause a limited ability to export and a significant dependence of economic growth on imports of important resources from abroad.

Thus, the factors that affect the functioning of the financial mechanism of the enterprise are marked by the influence they exert. Interacting with each other the factors of influence significantly affect the state of financial resources of economic entities and its further development. Using the specific functions of the financial mechanism stabilization, adaptation and protection of economic entities with common elements, identify and assess imbalances risks, maintain the financial stability and solvency of economic entities, maintain the balance of financial flows and the distribution of financial resources.

The main feature of 2015-2019 is the strengthening of globalization. The intensification of relations between the countries leads to a stronger integration of the whole economy which in turn creates additional risks associated with the transmission of possible crises in the chain.

By assessing the imbalances of the economic space on the basis of macroeconomic and monetary indicators obtained during the monitoring, businesses will be able to counteract shocks in the event of a change in the situation.

\section{References:}

Aleskerova, Yu., Mulyk, T., \& Fedoryshyna, L. (2018). Improving credit protection analysis methods Reports of main agricultural enterprises. Baltic Journal of Economic Studies, vol. 4, no. 2, pp. 1-7. doi: 10.30525/2256-0742/2018-4-2-1-7

Aleskerova, Yu., \& Fedoryshyna, L. (2018). Analysis of investment activities of enterprises of Ukraine. Economic system development trends: the experience of countries of Eastern Europe and prospects of Ukraine. doi: https://doi.org/10.30525/978-9934-571-28-2_1

Aleskerova, Yu., Fedoryshyna, L., \& Koval, N. (2018). Features of loan security for the reproduction of fixed assets for agricultural purposes. Baltic Journal of Economic Studies, vol. 4, no. 4, pp. 1-5. doi: 10.30525/2256-0742/2018-4-4-1-5

Aleskerova, Y., Kovalenko, L., \& Havryliuk, V. (2019). Innovative financial criteria for methodological approaches to the assessment of agrarian insurance. Baltic Journal of Economic Studies, vol. 5, no. 4, pp. 34-41. doi: 10.30525/2256-0742/2019-5-4-34-41

Rogach, S., Vdovenko, L., \& Polishchuk, O. (2019). Agriculture of Ukraine under the joint policy of the European Union. Baltic Journal of Economic Studies, vol. 5, no. 3, pp. 178-183. doi: 10.30525/22560742/2019-5-3-178-183

Plakhtii, T., Fedoryshyna, L., \& Tomchuk, O. (2019). Socio-Economic component of preferential taxation of individuals' incomes. Baltic Journal of Economic Studies, vol. 5, no. 2, pp. 171-175. doi: 10.30525/2256-0742/2019-5-2-171-175

Koval, N., Priamuhina, N., \& Zhmurko, I. (2020). Analyz economic - financial experience of the world countries in the system of pension insurance. Baltic Journal of Economic Studies, vol. 6, no. 1, pp. 1-7.

David Ransom (2011). IF1 - Insurance, Legal \& Regulatory. Chartered Insurance Institute.

Donald B. Kraybill (1989). The riddle of Amish culture.

Schindler, R. M. (1994). Consumer Motivation for Purchasing Low-Deductible Insurance. In Marketing and Public Policy Conference Proceedings, vol. 4, pp. 147-155.

Kritzer, B.E. (1996). Privatizing social security: the Chilean experience. Social Security Bulletin, vol. 3, pp. 45-55. Kubicek (2005). Contribution rates to funded pension systems in the new member countries. Research in International Business and Finance, vol. 19, issue 2, pp. 266-280.

Bettendorf, Leon J. H. and Heijdra, Ben J. (2005). Population ageing and pension reform in a small open economy with non-traded goods. Journal of Economic Dynamics Control, vol. 6, pp. 265-290.

Nicoholas George (2002). Sweden's savers are kept pasted on state of their funds. Financial Times, March 25, p. 7. 